\title{
Acceptance of YouTube Applied to Dance Learning
}

\author{
Jon-Chao Hong, Mei-Lien Chen, and Jian-Hong Ye
}

\begin{abstract}
The application of social media in education, including the learning of artistic performance, is becoming increasingly popular. The research on the acceptance of artistic performance through social media is accumulating. Therefore, this study employs an integrated approach based on the technology acceptance model (TAM) to examine dance learners experiencing YouTube by combining design features and factors to explore the acceptance. A survey from the online dance learning fellowship was distributed to recruit YouTube users. Confirmatory factor analysis was adopted to confirm reliability and validity, and a structural equation modeling test by VisualPLS with maximum likelihood estimation was performed to identify the relationships among the constructs. The results suggest that attitudes toward learning dance positively contribute to both perceived usefulness and ease of use of YouTube. Also, both of the factors are important in terms of enhancing YouTube users' attitudes. Furthermore, positive relationships exist between YouTube users' attitudes toward using and intention to use. This study contributes to the extant literature by identifying the decisive impact of the acceptance of YouTube applied to dance learning, and a new perspective extending the TAM by measuring YouTube users' experience of intention to use is provided as a reference for further studies.
\end{abstract}

Index Terms-Dance learning, attitude of dance learning, TAM, social media, YouTube.

\section{INTRODUCTION}

\section{A. Information and Communication Technology (ICT) and Education}

In recent years, the growing ubiquity and influence of technology has made technology accessible to almost all areas in society [1], [2], making the Internet an essential platform for communication and a vital approach to accessing information in people's daily life [3]. Therefore, the rapid development of information and communication technology (ICT) has dramatically transformed education [4] Emerging information and technology provide a wide range of learning environments [5]. Emerging technologies have transformed the way students learn [6], and the use of information and communication technologies can promote active learning [7]. In addition, studies show positive results in terms of student outcomes as a result of the integration of video technology in instruction [8]. With the recent innovation of enhanced Internet speed, sharing multimedia content including images, audio, animation, and videos has become much easier and faster [9].

Manuscript received July 23, 2019; revised November 28, 2019.

The authors are with the Department of Industrial Education, National Taiwan Normal University, Taiwan (corresponding author: Jian-Hong Ye; e-mail: kimpo30107@yahoo.com.tw).

\section{B. YouTube and Dance Learning}

YouTube is one of the world's most popular websites and hosts numerous amateur and professional videos [10], accounting for a significant percentage of the Internet's global traffic [11]. YouTube is also a popular online video-sharing website for both scholarly and non-scholarly communication [12].

The field of dance could not remain unaffected considering that, throughout dance history, technology has always been a method of identification, dissemination, storage or display, whether we are referring to written texts or dance video systems, graphic applications or films [13]. Therefore, online videos may be useful for scholarly communication within the arts [14], while YouTube dance resources have become readily available online [15]. Using YouTube as a tool for teaching knowledge in the field of dance is useful and interactive [13]. However, studies related to the use of YouTube in education have focused mainly on academic achievement, with very few conducted in the instruction of the performing arts [16], or investigating student perceptions and usage of YouTube [17]. Although the study of social media acceptance and adoption is not a new research topic, the analysis of the educational and information systems (IS) theories/models that are used to examine social media acceptance and adoption is considered an important research direction [18]. Thus, this study hopes to explore the extent to which learners are more likely to learn dance through YouTube.

\section{Attitude toward Learning Dance}

The concept of attitude has been used widely in several social science disciplines to indicate a relatively stable evaluative stance of a person toward any object [19]. These terms refer to the tendency to evaluate certain people and things in a favorable or unfavorable manner. This tendency cannot be directly observed, but can be inferred from the individual's reaction [20]. Research indicates that student attitudes can have a strong impact on learning behavior [21]. Thus, the learner's attitude is very important and is considered to help to achieve the desired learning outcomes [22]. Learning attitude includes a wide range of connotations; for example, active learning and learning mentality, cognitive attitudes, time control, learning skills, time management, and hard work are all considered to be the meaning of learning attitudes [23]. Attitudes towards learning are the level of goal setting for learners, the ability to solve problems, and their beliefs towards learning [24]. The attitude of students is the backbone of teaching in any field [25]. Therefore, this study explores the attitude of learning dance as an external variable.

In summary, this study used TAM theory to test the relationship between users' attitude toward learning dance, perceived ease of using YouTube, perceived usefulness of 
YouTube, attitude toward use of YouTube and intention to use YouTube.

\section{CONCEPTUAL FramewORK AND RESEARCH HyPOTHESES}

\section{A. TAM Model}

The technology acceptance model (TAM) is an important tool for information technology research. Many scholars apply TAM to various research fields [26]. TAM explains users' acceptance of technology [27], and consists of several variables such as usefulness, ease of use, and behavioral attitudes toward technology. It provides an acceptable and effective explanation for the use of technology for explaining the intention to use technology either directly or indirectly [28], [29]. TAM is also considered a stable model to address consumer acceptance of innovative technologies [30]. This may affect people's belief in the system [31]. Moreover, the most important facet of the technology acceptance model is ease of use and usefulness [32]. Ease of use is defined as the degree to which no effort is required when using the technology [33], while usefulness is defined as the degree to which an individual believes that the use of a particular technology can improve user performance [34]. The technology acceptance model demonstrates the scientific acceptance of knowledge from external variables to internal variables [35]. This study uses TAM theory to detect the relationship between the attitude, ease of use, usefulness, attitude toward use and intention of users to learn dance via YouTube, and to analyze the results of the research and make specific recommendations.

\section{B. Research Hypotheses}

TAM is widely used to study the adoption of various technologies, and is arguably the most influential theory [31]. Still TAM assumes a positive correlation between ease of use and usefulness [36], while it points out that users' attitudes towards IT are determined by the two specific beliefs of usefulness and ease of use. This attitude also affects the intention to use technology [37]. In other words, the less complex the user's social media-related activities, the more likely they are to think that social media sites are useful [38]. In addition to TAM, this study also combines learning attitudes to explore the acceptance of learning dance based on YouTube. Therefore, we hypothesize the following:

- Hypothesis 1: Attitude toward learning dance is positively associated with perceived ease of using YouTube.

- Hypothesis 2: Attitude toward learning dance is positively associated with perceived usefulness of YouTube.

- Hypothesis 3: Perceived ease of using YouTube is positively associated with perceived usefulness of YouTube.

- Hypothesis 4: Perceived ease of using YouTube is positively associated with attitude toward use of YouTube.

- Hypothesis 5: Perceived usefulness of YouTube is positively associated with attitude toward use of YouTube
- Hypothesis 6: Attitude toward use of YouTube is positively associated with intention to use YouTube.

\section{Research Model}

The Technology Acceptance Model (TAM) was proposed by Davis (1989) to explore the reasons why users accept or reject information technology [39]. Therefore, this study uses the TAM proposed by Davis (1989) as the basis to investigate the dance learners who use YouTube [39]. In order to test the six research hypotheses proposed, this study used the data obtained from the questionnaire for structural equation modeling analysis.

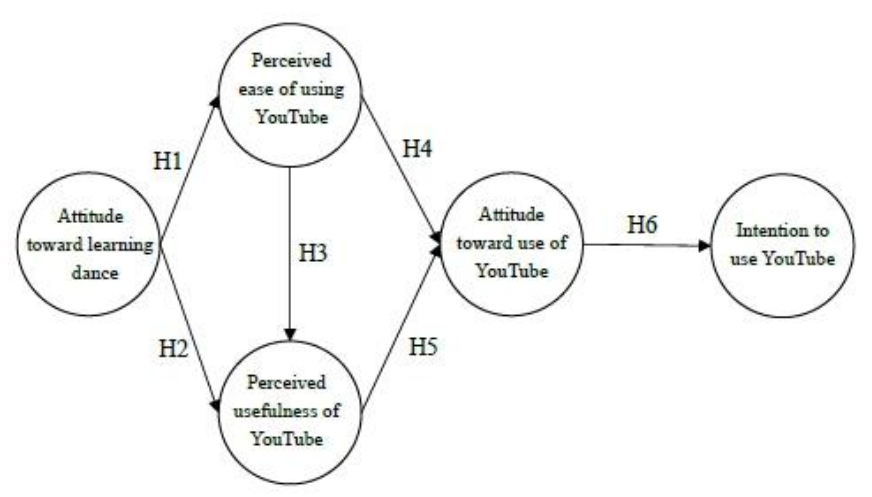

Fig. 1. Research model.

\section{RESEARCH DESIGN}

\section{A. Participants}

This study facilitated the sampling of online questionnaires through the online dance community and invited the dance learners who use YouTube to fill out the questionnaire from November 12 to December 23, 2018. A total of 241 questionnaires were collected. After the invalid data were deleted, there were 196 valid data, and the effective recovery rate was $81.3 \%$, including 74 males and 122 females. There were 103 people aged 20 years and younger, 83 aged 21 to 25 years old, and 10 over the age of 25 . Regarding experience of learning dance, there were 145 with less than three years' experience, 25 with three to five years, and 26 with over five years.

\section{B. Survey Instruments}

This research aimed to use a reliable, validated measure to collect data. The items in the questionnaire were constructed by adopting those from previous studies and related theories, and was verified by the experts. The questionnaire included five constructs and the items were fully anchored using a 5-point Likert-type scale that ranged from 1, strongly disagree, to 5, strongly agree. After the questionnaires were collected, confirmatory factor analysis was performed, then SPSS 23 was applied to analyze the reliability and validity of these items, confirm the credibility of the scale tool, and use structural equation modeling with partial least squares (PLS) to verify the research model.

Attitude has a theme, called an object or goal, which can be an object, a person, or an abstract idea [40]. Based on this definition and with reference to the relevant literature, a dance attitude scale was developed to measure participants' perceptions of their attitudes toward learning dance including 
items such as, "If I see the dance movements I want to imitate, I will continue to watch repeatedly." Therefore, the TAM questionnaire was compiled from Hong et al.'s (2011) scale to measure participants' perceived ease of use, perceived usefulness, attitude toward use, and intention to use YouTube [37].

\section{RESULTS}

In this study, the partial least squares (PLS) method is considered to be an ideal research tool with a small sample size [41], [42]. AMOS 20 was applied to analyze the questionnaire items and constructs, and SPSS 23 with VisualPLS 1.04b1a was used to conduct reliability analysis, validity analysis, and model fit verification.

\section{A. Item Analysis}

First-order confirmatory factor analysis (CFA) was used to assess the questionnaire items. This study adopted the recommendations to set $\chi^{2} / \mathrm{df}$ of the constructs to less than the threshold value of 5. For the Root Mean Square Error of Approximation (RMSEA), a threshold value less than 0.1 indicates a good fit. For Goodness-of-fit (GFI) and Adjusted Goodness-of-fit (AGFI), the threshold value above 0.8 is accepted. For all items with factor loadings (FL), the threshold value should be significant and higher than 0.5 [43] [44]. Consequently, the items retained for the five constructs were as follows: four for the attitude of learning dance, five for the perceived ease of using YouTube, four for the perceived usefulness of YouTube, three for the attitude toward use of YouTube, and three for the intention to use YouTube.

TABLE I: ITEM ANALYSIS BY FIRST-ORDER CONFIRMATORY FACTOR

\begin{tabular}{ccccccc}
\multicolumn{7}{c}{ ANALYSIS } \\
\hline Index & $\chi^{2}$ & df. & $\chi^{2} /$ df. & RMSEA & GFI & AGFI \\
\hline Threshold & --- & --- & $<5$ & $<.100$ & $>.800$ & $>.800$ \\
Attitude toward & 1.4 & 2 & .7 & .000 & .996 & .982 \\
$\quad$ learning dance & & & & & & \\
Perceived ease of using & 19.8 & 9 & 2.2 & .078 & .968 & .925 \\
Perceived usefulness & 21.4 & 9 & 2.4 & .084 & .966 & .920 \\
Attitude toward use & 2.9 & 2 & 1.5 & .048 & .993 & .964 \\
Intention to use & 12.1 & 5 & 2.4 & .086 & .975 & .925 \\
\hline
\end{tabular}

The scope of interpretation is judged by the measure of the external validity of the items [45]. The scale was examined by independent $t$ tests to explain the discriminative power of each item. One frequently used technique for assessing whether an item is properly discriminating is to select those in the top and bottom $27 \%$ of the subscale score distribution to test whether there is a statistically significant difference between the two groups' mean scores on the item. If the critical ratio ( $t$ value) is larger than $3\left(p^{* * *}<.001\right)$, the discriminative power is significant. Table II shows that all critical ratios ( $t$ values) were larger than $48.105\left(p^{* * *}\right.$ $<0.001$ ), indicating that the subscales also reached significance, thus suggesting that all items were discriminative [46].

\section{B. Reliability and Validity Analyses of the Questionnaire}

This study confirmed the internal consistency of the test scale via Cronbach's $\alpha$ and retested the reliability with a composite reliability (CR). According to Tabbakh and Freeland-Graves (2016), when Cronbach's $\alpha$ value is above .600, it is acceptable [47]. Hair et al. (2010) suggested that the $\mathrm{CR}$ value of a construct is acceptable when it is above .700 [43]. All the Cronbach's $\alpha$ values of this study ranged from .727 to .857 , and the $\mathrm{CR}$ values ranged from .782 to .877 , which suggested that the internal construct consistency and reliability was confirmed for further analysis.

With respect to the convergent validity, this study is assessed by factor loading (FL) and average variance extracted (AVE). Hair et al. (2010) stated that the FL value should be above .500 , and that items below this value should be deleted [43]. All the items retained in this study are in conformity with the standards recommended, such as the FL values of attitude of learning dance ranging from .692 to .856 , the perceived ease of using YouTube ranging from .687 to .789 , the perceived usefulness of YouTube ranging from .562 to .845 , the attitude toward use of YouTube ranging from .692 to .841 , and the intention to use YouTube ranging from .721 to .920. In addition, Hair, Ringle, and Sarstedt (2011) suggest that the AVE value must be greater than .500 to indicate that the construct has sufficient convergence validity [48]. Table II shows that the AVE Values for the constructs ranged from .543 to .674 , which indicates that all constructs in this study obtained convergent validity.

\section{TABLE II: RELIABILITY AND VALIDITY ANALYSIS OF THE ITEMS}

\begin{tabular}{|c|c|c|c|c|}
\hline Items & $\mathrm{M}$ & SD & FL & $t$ value \\
\hline \multicolumn{5}{|l|}{$\begin{array}{l}\text { Attitude toward learning dance } \\
\mathrm{M}=3.843, \mathrm{SD}=.810, \text { Cronbach's } \alpha\end{array}$} \\
\hline $\begin{array}{l}\text { 1. I will watch the dance videos } \\
\text { I like repeatedly. }\end{array}$ & 4.38 & .866 & .760 & 70.837 \\
\hline $\begin{array}{l}\text { 2. If I see the dance steps I like, I } \\
\text { will practice until I am } \\
\text { familiar with them. }\end{array}$ & 3.67 & 1.066 & .882 & 48.193 \\
\hline $\begin{array}{l}\text { 3. When I see the dance } \\
\text { movements I want to imitate, I } \\
\text { will continue to watch them } \\
\text { over and over again. }\end{array}$ & 3.65 & 1.063 & .856 & 48.105 \\
\hline $\begin{array}{l}\text { 4. For different styles of dance, I } \\
\text { will try to follow the film. }\end{array}$ & 3.67 & 1.051 & .692 & 48.860 \\
\hline \multicolumn{5}{|c|}{$\begin{array}{l}\text { Perceived ease of using YouTube } \\
\mathrm{M}=4.405, \mathrm{SD}=0551, \mathrm{Cronbach} \text { 's } \alpha=.798, \mathrm{CR}=.856, \mathrm{AVE}=.543\end{array}$} \\
\hline $\begin{array}{l}\text { 1. I think using YouTube is } \\
\text { simple. }\end{array}$ & 4.57 & .616 & .758 & 103.892 \\
\hline $\begin{array}{l}\text { 2. I know how to search for } \\
\text { dance-related videos on } \\
\text { YouTube. }\end{array}$ & 4.49 & .691 & .738 & 91.125 \\
\hline $\begin{array}{l}\text { 3. I am watching the } \\
\text { dance-related videos from } \\
\text { YouTube to help me learn. I } \\
\text { think it is very simple. }\end{array}$ & 4.20 & .803 & .687 & 73.268 \\
\hline $\begin{array}{l}\text { 4. When I have time, I find it } \\
\text { easy to browse videos on } \\
\text { YouTube. }\end{array}$ & 4.38 & .744 & .709 & 82.327 \\
\hline $\begin{array}{l}\text { 5. I am more likely to browse } \\
\text { YouTube videos than to read } \\
\text { books. }\end{array}$ & 4.30 & .787 & .789 & 76.401 \\
\hline \multicolumn{5}{|c|}{$\begin{array}{l}\text { Perceived usefulness of YouTube } \\
\mathrm{M}=4.602, \mathrm{SD}=.68, \text { Cronbach's } \alpha=.851, \mathrm{CR}=.857, \mathrm{AVE}=.599\end{array}$} \\
\hline $\begin{array}{l}\text { 1. I think YouTube's dance film } \\
\text { inspired me to learn about } \\
\text { dance. }\end{array}$ & 3.94 & .845 & .864 & 65.251 \\
\hline $\begin{array}{l}\text { 2. By using YouTube, I can } \\
\text { increase my understanding of } \\
\text { all types of dance. }\end{array}$ & 4.08 & .777 & .562 & 73.412 \\
\hline
\end{tabular}




\begin{tabular}{|c|c|c|c|c|}
\hline Items & M & SD & FL & $t$ value \\
\hline $\begin{array}{l}\text { 3. With YouTube, I can } \\
\text { continue to learn a variety of } \\
\text { dance moves. }\end{array}$ & 4.00 & .829 & .898 & 67.554 \\
\hline $\begin{array}{l}\text { 4. With YouTube, I can see the } \\
\text { different dance performances } \\
\text { augmented. }\end{array}$ & 4.23 & .820 & .725 & 72.276 \\
\hline
\end{tabular}

\begin{tabular}{|c|c|c|c|c|c|c|}
\hline \multicolumn{7}{|c|}{$\begin{array}{l}\text { Attitude toward use of YouTube } \\
\mathrm{M}=3.969, \mathrm{SD}=.595, \text { Cronbach's } \alpha=.727, \mathrm{CR}=.782, \mathrm{AVE}=.546\end{array}$} \\
\hline \multicolumn{3}{|c|}{$\begin{array}{l}\text { to YouTube’s "Favorite } \\
\text { Videos". }\end{array}$} & 4.10 & .784 & .841 & 73.220 \\
\hline \multicolumn{3}{|c|}{$\begin{array}{l}\text { 2. If I don't have time to watch } \\
\text { the video, I will put it in "view } \\
\text { later" on YouTube. }\end{array}$} & 3.93 & .713 & 692 & 77.190 \\
\hline \multicolumn{3}{|c|}{$\begin{array}{l}\text { 3. I will subscribe to the } \\
\text { YouTube user channel for } \\
\text { regular dance videos. }\end{array}$} & 3.88 & .857 & 673 & 63.378 \\
\hline \multicolumn{7}{|c|}{ Intention to use YouTube } \\
\hline \multicolumn{3}{|c|}{$\begin{array}{l}\text { 1. As long as I learn the new } \\
\text { dance steps, I will watch } \\
\text { YouTube first. }\end{array}$} & 3.83 & .881 & .809 & 60.870 \\
\hline \multicolumn{3}{|c|}{$\begin{array}{l}\text { 2. I will try to use the YouTube } \\
\text { dance videos to learn new } \\
\text { dance steps. }\end{array}$} & 3.6 & .884 & .920 & 57.304 \\
\hline \multicolumn{3}{|c|}{$\begin{array}{l}\text { 3. I will try to use the YouTube } \\
\text { dance videos to increase my } \\
\text { understanding of various } \\
\text { dances. }\end{array}$} & 3.7 & .886 & .721 & 59.141 \\
\hline \multicolumn{7}{|c|}{ TABLE III: CONSTRUCT DISCRIMINATIVE VALIDITY } \\
\hline Constructs & $\begin{array}{l}\text { Attitude } \\
\text { toward } \\
\text { learning } \\
\text { dance } \\
\end{array}$ & $\begin{array}{r}\text { Perc } \\
\text { eas } \\
\text { us } \\
\text { You }\end{array}$ & & $\begin{array}{l}\text { Perceived } \\
\text { usefulnes } \\
\text { s of } \\
\text { YouTube }\end{array}$ & $\begin{array}{l}\text { Attitude } \\
\text { toward } \\
\text { use of } \\
\text { YouTube }\end{array}$ & $\begin{array}{l}\text { Intention } \\
\text { to use } \\
\text { YouTube }\end{array}$ \\
\hline $\begin{array}{c}\text { Attitude } \\
\text { toward } \\
\text { learning dance }\end{array}$ & $(.801)$ & & & & & \\
\hline $\begin{array}{l}\text { Perceived ease } \\
\text { of using } \\
\text { YouTube }\end{array}$ & $.329 * *$ & $(.7$ & & & & \\
\hline $\begin{array}{l}\text { Perceived } \\
\text { usefulness of } \\
\text { YouTube }\end{array}$ & $.512 * *$ & .38 & & $(.774)$ & & \\
\hline $\begin{array}{l}\text { Attitude } \\
\text { toward use of } \\
\text { YouTube }\end{array}$ & $.380 * *$ & .40 & & $.389 * *$ & $(.739)$ & \\
\hline $\begin{array}{l}\text { Intention to } \\
\text { use YouTube }\end{array}$ & $.424 * *$ & .30 & & $.634 * *$ & $.401 * *$ & $(.821)$ \\
\hline
\end{tabular}

\section{Path Analysis}

In the verification step, this study adopted SPSS 23 to analyze the learning achievement, and then AMOS 20 was used to determine the overall fit degree of the relationships illustrated in the proposed model. Among them, the goodness of fit (GoF) value of 0.375 exceeded the medium cut-off value of 0.25 proposed by Hoffmann and Birnbrich (2012), indicating that our model has a good global model fit [49].

The structural equation modeling was adopted to identify the proposed hypotheses and model significance. Fig. 2 illustrates the hypothesized structural model that was evaluated by the maximum likelihood estimation method. The SEM results indicated that significant positive relationships existed between the attitude of learning dance and the perceived ease of using YouTube $\left(\beta=.340^{* * *} ; t=\right.$ 5.711) and the perceived usefulness of YouTube $(\beta$ $\left.=.475^{* * * ;} t=6.366\right)$. Thus, Hypotheses 1 and 2 were supported. The perceived ease of using YouTube was found to exert a significant influence on the perceived usefulness of YouTube $\left(\beta=.220^{* *} ; t=2.720\right)$, which indicated that Hypothesis 3 was supported. The perceived ease of using YouTube $\left(\beta=.313^{* * *} ; t=4.268\right)$ and the perceived usefulness of YouTube $(\beta=.352 * * * ; t=4.494)$ were revealed to significantly affect the attitude toward use of YouTube, which confirmed Hypotheses 4 and 5. Furthermore, Hypothesis 6 was supported as the significant relationship was revealed between the attitude toward use of YouTube and the intention to use YouTube $\left(\beta=.414^{* * *} ; t=\right.$ 5.536). The attitude of learning dance to the perceived ease of using YouTube is $11.6 \%, f^{2}$ is .131 , the attitude of learning dance and the perceived ease of using YouTube explains that the perceived usefulness of YouTube is $34.5 \%, f^{2}$ is .527 , the perceived ease of using YouTube and the perceived usefulness of YouTube for the explanatory power of attitude towards YouTube is $30.6 \%, f^{2}$ is .441 . The explanatory power of attitude toward use of YouTube for the intention to use YouTube is $17.1 \%$ and $f^{2}$ is .206 .

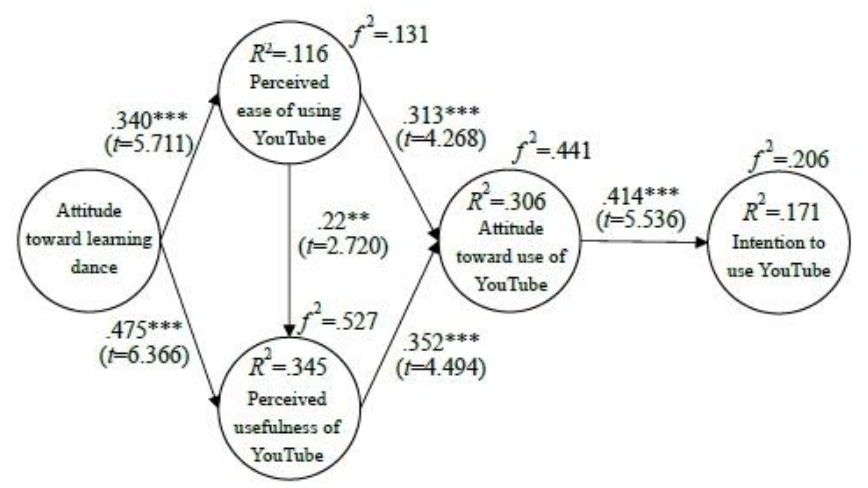

Fig. 2. Verification of the research model.

\section{DISCUSSION}

Attitude has a theme (called an object or goal), which can be an object, a person or an abstract idea [40], and the results show that the participants in this study have a good attitude toward learning dance $(M=3.843, S D=.810)$. In addition, the technology acceptance literature has emerged over the past three decades to provide empirical models that influence the prior beliefs of technology adoption and use [50]. The results of the study showed that the participants had a good perception of the various constructs of the technical acceptance model, among which are ease of using YouTube $(M=4.405, S D=.551)$, the perceived usefulness of YouTube $(M=4.602, S D=.680)$, the attitude toward use of YouTube $(M=3.969, S D=.595)$, and the intention to use YouTube $(M$ $=3.730, S D=.730$ ).

In addition, TAM explains the pathways of technology acceptance from external variables to internal variables, such as external variables to beliefs, attitudes, and system use [35] [51]. The results of this study show that the attitude of learning dance is positively related to the perceived ease of using YouTube and the perceived usefulness of YouTube. At the same time, Chang, Hajiyev, and $\mathrm{Su}$ (2017) and Teo (2011) pointed out the relationship between ease of use and usefulness [52], [53]. Similarly, the results of this study show that the perceived ease of using YouTube is positively related 
to the perceived usefulness of YouTube.

Furthermore, Amoako-Gyampah and Salam (2004) believe that the usefulness and ease of use of information technology in TAM theory is the main determinant of its use [54], and ease of use and usefulness often affect users for different user types and e-learning techniques. The factors set the attitude of using e-learning technology equally [55], while the studies by Hong et al. (2011) and Teo et al. (2008) pointed out that usefulness and ease of use are the main factors to use reason [37], [56]. The results of the study showed that the perceived ease of using YouTube and the perceived usefulness of YouTube were positively correlated with the attitude toward use of YouTube.

The technology acceptance model predicts the willingness to use technology [50], and the use of systematic attitudes determines behavioral willingness [53], [57]. The results also show that the attitude toward use of YouTube is positively correlated with the intention to use YouTube.

\section{CONCLUSION}

The ever-changing technology, the development of Internet technology and the new way of information sharing have promoted the emergence of various digital teaching and learning programs [58]. However, learners' acceptance of emerging technologies and educational technologies will affect the learning process and outcomes. Therefore, it is important to explore how acceptable they are to learners when using educational technology systems.

Based on social psychology research, TAM combines a variety of theoretical perspectives with scientific methods. TAM has been widely recognized for its simplicity and parsimony [59], and has evolved to understand human behavior. Predictive factors for the potential acceptance or rejection of key models of technology have been identified [31]. From the results, this study believes that learning dance through YouTube can provide students with good knowledge, which can in turn increase their chances of continuing to learn dance. At the same time, the results of this study suggest that it is feasible to learn performing arts through social media.

\section{LIMITATIONS AND FUTURE STUDIES}

Gender differences are also important in terms of science and technology acceptance, as there have been significant differences in the attitudes of women and men over time which are of interest to research [57], [60]. In this study, it was not explored whether there was a difference in the acceptance of dance learning by different gender learners on YouTube, so this issue can be explored in subsequent studies.

Besides, future exploration can use the cognitive-affective based model to examine learners' flow experience [61]. Follow-up studies can also explore the influence of social media on dance knowledge.

\section{CONFLICT OF INTEREST}

The authors declare no conflict of interest.

\section{INTEREST AND AUTHOR CONTRIBUTION}

First author conducted the research; second and third author analyzed the data; all authors wrote the paper; all authors had approved the final version.

\section{ACKNOWLEDGEMENT}

This work was financially supported by the "Institute for Research Excellence in Learning Sciences" of National Taiwan Normal University (NTNU) from The Featured Areas Research Center Program within the framework of the Higher Education Sprout Project by the Ministry of Education (MOE) in Taiwan.

\section{REFERENCES}

[1] T. Doleck, P. Bazelais, and D. J. Lemay, "The role of behavioral expectation in technology acceptance: A CEGEP case study," Journal of Computing in Higher Education, vol. 30, no. 3, pp. 407-425, 2018.

[2] R. Scherer, F. Siddiq, and J. Tondeur, "The technology acceptance model (TAM): A meta-analytic structural equation modeling approach to explaining teachers' adoption of digital technology in education," Computers \& Education, no. 128, pp. 13-35, 2019.

[3] Y. Lu, S., Papagiannidis, and E. Alamanos, "Exploring the emotional antecedents and outcomes of technology acceptance," Computers in Human Behavior, no. 90, pp. 153-169, 2019.

[4] F. Huang, T. Teo, and M. Zhou, "Factors affecting Chinese English as a foreign language teachers' technology acceptance: A qualitative study," Journal of Educational Computing Research, vol. 57, no. 1, pp. 83-105, 2019.

[5] S. Liao, J. C. Hong, M. H. Wen, Y. C. Pan, and Y. W. Wu, "Applying technology acceptance model (TAM) to explore users' behavioral intention to adopt a performance assessment system for e-book production," EURASIA Journal of Mathematics, Science and Technology Education, no. 14, em1601, 2018.

[6] S. A. Azer, "Can YouTube help students in learning surface anatomy?" Surgical and Radiologic Anatomy, vol. 34, no. 5, pp. 465-468, 2012.

[7] F. M. E. Mon and M. G. Cervera, "El nuevo paradigma de aprendizaje y nuevas tecnologías. REDU," Revista de Docencia Universitaria, vol. 9 , no. 3, pp. 55-73, 2011.

[8] T. Jones and K. Cuthrell, "YouTube: Educational potentials and pitfalls," Computers in the Schools, vol. 28, no. 1, pp. 75-85, 2011.

[9] C. Park, D. G. Kim, S. Cho, and H. J. Han, "Adoption of multimedia technology for learning and gender difference," Computers in Human Behavior, no. 92, pp. 288-296, 2019.

[10] M. Thelwall, P. Sud, and F. Vis, "Commenting on YouTube videos: From Guatemalan rock to el big bang," Journal of the American Society for Information Science and Technology, vol. 63, no. 3, pp. 616-629, 2012.

[11] P. Ameigeiras, J. J. Ramos-Munoz, J. Navarro-Ortiz, and J. M. Lopez-Soler, "Analysis and modelling of YouTube traffic," Transactions on Emerging Telecommunications Technologies, vol. 23, no. 4, pp. 360-377, 2012.

[12] S. C. Burke, S. Snyder, and R. C. Rager, "An assessment of faculty usage of YouTube as a teaching resource," Internet Journal of Allied Health Sciences and Practice, vol. 7, no. 1, pp. 1-8, 2009.

[13] D. Gratsiouni, M. Koutsouba, F. Venetsanou, and V. Tyrovola, "Learning and digital environment of dance-the case of Greek traditional dance in YouTube," European Journal of Open, Distance and e-Learning, vol. 19, no. 2, pp. 80-95, 2016.

[14] K. Kousha, M. Thelwall, and M. Abdoli, "The role of online videos in research communication: A content analysis of YouTube videos cited in academic publications," Journal of the American Society for Information Science and Technology, vol. 63, no. 9, pp. 1710-1727, 2012.

[15] B. Lepczyk, "Technology facilitates teaching and learning in creative dance," Journal of Physical Education, Recreation \& Dance, vol. 80, no. 6, pp. 4-8, 2009

[16] D. DeWitt, N. Alias, S. Siraj, M. Y. Yaakub, J. Ayob, and R. Ishak, "The potential of YouTube for teaching and learning in the performing arts," Procedia-Social and Behavioral Sciences, no. 103, pp. 1118-1126, 2013.

[17] I. Duncan, L. Yarwood-Ross, and C. Haigh, "YouTube as a source of clinical skills education," Nurse Education Today, vol. 33, no. 12, pp. 1576-1580, 2013. 
[18] N. Al-Qaysi, N. Mohamad-Nordin, and M. Al-Emran, "A systematic review of social media acceptance from the perspective of educational and information systems theories and models," Journal of Educational Computing Research, in press.

[19] C. Fleck, "Attitude: History of concept," International Encyclopedia of the Social \& Behavioral Sciences, 2nd ed., Amsterdam, NL: Elsevier, 2015, pp. $178-182$.

[20] N. Schwarz, "Attitude measurement," International Encyclopedia of the Social \& Behavioral Sciences, 2nd ed., Amsterdam, NL: Elsevier, 2015, pp. 178-182.

[21] J. Arbaugh, "Sage, guide, both, or even more? An examination of instructor activity in online MBA courses," Communication Education, vol. 55, no. 3, pp. 1234-1244, 2010.

[22] M. C. Chong, K. Francis, S. Cooper, K. L. Abdullah, N. T. T. Hmwe, and S. Sohod, "Access to, interest in and attitude toward e-learning for continuous education among Malaysian nurses," Nurse Education Today, no. 36, pp. 370-374, 2016.

[23] C. J. Huang and W. T. Huang, "Relationships among family resources, learning attitudes, university admission channels, and learning performance: Case of a Taiwanese university," Journal of Research in Education Sciences, vol. 62, no. 4, pp. 117-1430, 2017.

[24] H. S. Sen, "The attitudes of university students towards learning," Procedia-Social and Behavioral Sciences, no. 83, pp. 947-953, 2013.

[25] N. González-García, A. B. Sánchez-García, A. B. Nieto-Librero, and M. P. Galindo-Villardón, "Attitude and learning approaches in the study of general Didactics: A multivariate analysis," Revista de Psicodidáctica (English ed.), in press.

[26] Y. Li, J. Qi, and H. Shu, "Review of relationships among variables in TAM," Tsinghua Science \& Technology, vol. 13, no. 3, pp. 273-278, 2008.

[27] F. D. Davis, R. P. Bagozzi, and P. R. Warshaw, "User acceptance of computer technology: A comparison of two theoretical models," Management Science, vol. 35, no. 8, pp. 982-1003, 1989.

[28] M. Marchand, and L. Raymond, "Researching performance measurement systems," International Journal of Operations and Production Management, vol. 28, no. 7, pp. 663-686, 2008.

[29] J. Schepers and M. Wetzels, "A meta-analysis of the technology acceptance model: Investigating subjective norm and moderation effects," Information \& Management, vol. 44, no. 1, pp. 90-103, 2007.

[30] Y. Wang, S. Wang, J. Wang, J. Wei, and C. Wang, "An empirical study of consumers' intention to use ride-sharing services: Using an extended technology acceptance model," Transportation, in press.

[31] N. Marangunić and A. Granić, "Technology acceptance model: A literature review from 1986 to 2013," Universal Access in the Information Society, vol. 14, no. 1, pp. 81-95, 2015.

[32] S. Sunny, L. Patrick, and L. Rob, "Impact of cultural values on technology acceptance and technology readiness," International Journal of Hospitality Management, no. 77, pp. 89-96, 2019.

[33] K. M. Faqih and M. I. R. M. Jaradat, "Assessing the moderating effect of gender differences and individualism-collectivism at individual-level on the adoption of mobile commerce technology: TAM3 perspective," Journal of Retailing and Consumer Services, no. 22, vol. 37-52, 2015.

[34] T. Chi, "Understanding Chinese consumer adoption of apparel mobile commerce: An extended TAM approach," Journal of Retailing and Consumer Services, no. 44, pp. 274-284, 2018.

[35] M., Xia, Y. Zhang, and C. Zhang, "A TAM-based approach to explore the effect of online experience on destination image: A smartphone user's perspective," Journal of destination marketing \& management, no. 8, pp. 259-270, 2018.

[36] V. Venkatesh, and F. D. Davis, "A theoretical extension of the technology acceptance model: Four longitudinal field studies," Management Science, vol. 46, no. 2, pp. 186-204, 2000.

[37] J. C. Hong, M. Y. Hwang, H. F., Hsu, W. T. Wong, and M. Y. Chen, "Applying the technology acceptance model in a study of the factors affecting usage of the Taiwan digital archives system," Computers \& Education, vol. 57, no. 3, pp. 2086-2094, 2011.

[38] D. Z. Dumpit and C. J. Fernandez, "Analysis of the use of social media in higher education institutions (HEIs) using the technology acceptance model," International Journal of Educational Technology in Higher Education, vol. 14, no. 1, pp. 5:1-5:16, 2017.

[39] F. D. Davis, "Perceived usefulness, perceived ease of use, and user acceptance of information technology," MIS Quarterly, vol. 13, no. 3, pp. 319-340, 1989.

[40] D. Albarracin and S. Shavitt, "Attitudes and attitude change," Annual Review of Psychology, no. 69, pp. 299-327, 2018.

[41] W. W. Chin, B. L. Marcolin, and P. R. Newsted, "A partial least squares latent variable modeling approach for measuring interaction effects: Results from a monte carlo simulation study and an electronic-mail emotion/adoption study," Information Systems Research, vol. 14, no. 2, pp. 189-217, 2003.

[42] M. Y. Cheung, C. Luo, C. L. Sia, and H. Chen, "Credibility of electronic word-of-mouth: Informational and normative determinants of on-line consumer recommendations," International Journal of Electronic Commerce, vol. 13, no. 4, pp. 9-38, 2009.

[43] J. F. Hair, W. C. Black, B. J. Babin, and R. E. Anderson, "Multivariate data analysis, 7th ed.," Upper Saddle River, NJ: Pearson Prentice Hall, 2010.

[44] D. A. Kenny, B. Kaniskan, and D. B. McCoach, "The performance of RMSEA in models with small degrees of freedom," Sociological Methods \& Research, vol. 44, no. 3, pp. 486-507, 2015

[45] M. K. Cor, "Trust me, it is valid: Research validity in pharmacy education research," Currents in Pharmacy Teaching and Learning, vol. 8, no. 3, pp. 391-400, 2016.

[46] S. B. Green and N. Salkind, Using SPSS for Windows and Macintosh: Analyzing and Understanding Data, Englewood Cliffs, NJ Prentice-Hall, 2004.

[47] T. Tabbakh and J. Freeland-Graves, "Development and validation of the multidimensional home environment scale (MHES) for adolescents and their mothers," Eating Behaviors, no. 22, pp. 76-82, 2016

[48] J. F. Hair, C M. Ringle, and M. Sarstedt, "PLS-SEM: Indeed a silver bullet," Journal of Marketing Theory and Practice, vol. 19, no. 2, pp. 139-152, 2011.

[49] A. O. Hoffmann and C. Birnbrich, "The impact of fraud prevention on bank-customer relationships: An empirical investigation in retail banking," International Journal of Bank Marketing, vol. 30, no. 5, pp. 390-407, 2012

[50] D. J. Lemay, M. M. Morin, P. Bazelais, and T. Doleck, "Modeling students' perceptions of simulation-based learning using the technology acceptance model," Clinical Simulation in Nursing, no. 20, pp. 28-37, 2018.

[51] A. Burton-Jones and G. S. Hubona, "The mediation of external variables in the technology acceptance model," Information \& Management, vol. 43, no. 6, pp. 706-717, 2006.

[52] C. T. Chang, J. Hajiyev, and C. R. Su, "Examining the students' behavioral intention to use e-learning in Azerbaijan? The general extended technology acceptance model for e-learning approach," Computers \& Education, no. 111, vol. 128-143, 2017.

[53] T. Teo, "Factors influencing teachers' intention to use technology: Model development and test," Computers \& Education, vol. 57, no. 4 pp. 2432-2440, 2011.

[54] K. Amoako-Gyampah and A. F. Salam, "An extension of the technology acceptance model in an ERP implementation environment," Information \& Management, vol. 41, no. 6, pp. 731-745, 2004.

[55] B. ŠUmak, M. HeričKo, and M. Pušnik, "A meta-analysis of e-learning technology acceptance: The role of user types and e-learning technology types," Computers in Human Behavior, vol. 27, no. 6, pp. 2067-2077, 2011.

[56] T. Teo, C. B. Lee, and C. S. Chai, "Understanding pre-service teachers' computer attitudes: Applying and extending the technology acceptance model," Journal of Computer Assisted Learning, vol. 24, no. 2, pp. 128-143, 2008.

[57] J. C. Roca, C. M. Chiu, and F. J. Martínez, "Understanding e-learning continuance intention: An extension of the technology acceptance model," International Journal of Human-Computer Studies, vol. 64, no. 8, pp. 683-696, 2006

[58] R. Estriegana, J.-A. Medina-Merodio, and R. Barchino, "Student acceptance of virtual laboratory and practical work: An extension of the technology acceptance model," Computers \& Education, no. 135, pp. 1-14, 2019.

[59] V. Dutot, V. Bhatiasevi, and N. Bellallahom, "Applying the technology acceptance model in a three-countries study of smartwatch adoption," The Journal of High Technology Management Research, in press.

[60] C. I. Maican, A. M. Cazan, R. C. Lixandroiu, and L. Dovleac, "A study on academic staff personality and technology acceptance: The case of communication and collaboration applications," Computers \& Education, no. 128, pp. 113-131, 2019.

[61] J. C. Hong, C. R. Tsai, C. Fan-Chiang, and M. Y. Hwang, "Mindfulness in learning safe sex via social media: Perspectives of personality and experiential value," Computers in Human Behavior, no. 64, pp. 337-346, 2016.

Copyright $\odot 2020$ by the authors. This is an open access article distributed under the Creative Commons Attribution License which permits unrestricted use, distribution, and reproduction in any medium, provided the original work is properly cited (CC BY 4.0). 


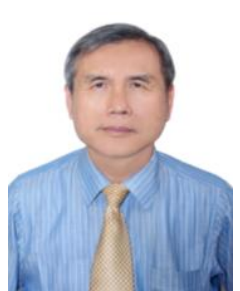

Jon-Chao Hong is a chair professor in Institute for Research Excellence in Learning Sciences, National Taiwan Normal University. Dr. Hong was granted two "Outstanding Research Award" given by the Ministry of Science and Technology in Taiwan. Dr. Hong's main research interests include digital learning, game-based learning, inquiry learning, STEAM education.

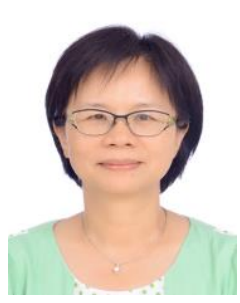

Mei-Lien Chen is a PhD student at the Department of Industrial Education, National Taiwan Normal University. She serves as a teacher at National Lan-Yang Girls' Senior High School. Ms. Chen's main research interests include digital learning, physics education.

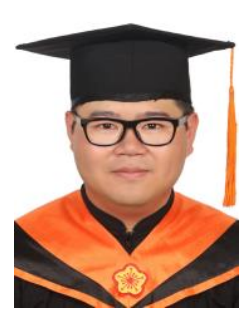

Jian-Hong Ye is a PhD student at the Department of Industrial Education, National Taiwan Normal University. He serves as a research assistant at the Department of Industrial Education, National Taiwan Normal University. Mr. Ye's main research interests include digital learning, game-based learning, design education and vocational education. 